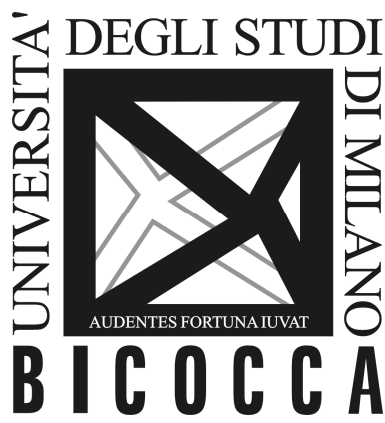

DEPARTMENT OF ECONOMICS

UNIVERSITY OF MILAN - BICOCCA

WORKING PAPER SERIES

\title{
A simple and flexible alternative to the Stability and Growth Pact deficit ceilings. Is it at hand?
}

V. Anton Muscatelli, Piergiovanna Natale, Patrizio

Tirelli

No. 195 - July 2010 


\author{
V. Anton Muscatelli \\ (University of Glasgow and CESifo, Munich) \\ Piergiovanna Natale \\ (Università di Milano Bicocca) \\ Patrizio Tirelli \\ (Università di Milano Bicocca)
}

This version:

4 May 2010

\begin{abstract}
We use a simple theoretical model of a monetary union where myopic discretionary fiscal policies generate excessive debt accumulation in steady state and inefficiently delayed debt adjustment following a shock. We advocate the adoption of a flexible debt targeting approach. By setting a long-term debt target and by raising the political cost associated to deviations from the optimal pace of debt reversal following a shock, institutional design induces the fiscal policymaker to implement unbiased discretionary responses to shocks. Since the power to discipline fiscal policymakers rests in the hands of national voters, this outcome can be achieved by increasing the transparency of the decision-making process, where national voters understand the long-term consequences of fiscal policies. In practice, we call for clearer and more focused supervision tasks for the European Commission and for a more active role of national Parliaments whenever a disagreement arises between the Commission and a national government.
\end{abstract}

\title{
JEL Codes: E52, E61, E63
}

Corresponding author

Piergiovanna Natale

Università di Milano Bicocca

Piazza dell'Ateneo Nuovo 1

20126 Milano

piergiovanna.natale@unimib.it

tel. +390264483095

fax +390264483085

\footnotetext{
${ }^{*}$ This is a completely revised version of CESifo Working Paper n. 1006. The authors wish to thank for very useful comments Enzo Dia and Jacques Melitz.
} 


\section{Introduction}

The Maastricht Treaty and the Stability and Growth Pact (SGP) provide the institutional framework that regulates fiscal policies within the European Monetary Union. Adopted in 1997, the SGP stipulated that countries should aim for public budgets close to balance or in surplus, and set a ceiling to national deficits as a proportion of GDP (3\%), making exception only for large adverse shocks. Shortly after its adoption, the SGP architecture was put under severe strain. Between 2001 and 2004 several countries breached the 3\% deficit ceiling. In November 2003, the European Council refused to endorse a recommendation by the Commission, requiring France and Germany to cut their budget deficits for 2004. Following a request by the European Council, in September 2004 the European Commission presented a set of changes to the Pact's provisions. Six months of heated debates and tough negotiations led to the adoption of a reformed SGP in March 2005. In the aftermath of the 2008 financial crisis, the new SGP allowed for budget deficits well beyond the 3\% deficit ceiling. Unfortunately, the crisis unveiled another weakness of the EMU institutional framework. In fact, it turned out that official figures for the Greek deficits had been systematically cooked before and after the country joined EMU in 2001 (Almunia, 2004). In 2009 the actual budget deficit was close to $13 \%$ of GDP, more than doubling the government forecasts in 2008 . This triggered fears that a Greek default could destabilise the Euro area. In this paper we review the working of the SGP after the 2005 reform and in the light of novel empirical evidence we advocate further reform.

The reformed SGP allows for greater discretion in the face of cyclical downturns, puts more emphasis on the long-term accumulation of debt and explicitly refers to structural deficits as a measure of long-term fiscal discipline. Early analyses of the reform pointed out that the new Pact would simply provide excessive flexibility (Buiter, 2005; Calmfors, 2005; Coeré and Pisani-Ferry, 2005). More recently, in the wake of the financial crisis that hit the world economy, EMU fiscal policies have been criticized for being too timid (IMF 2009). The empirical evidence presented in the paper points out that, despite its apparent flexibility, the new Pact has been associated with 
procyclical policies that reduced debt when business cycle conditions were deteriorating. Perhaps this could be justified as the hard price to be paid after the profligacy of the early EMU years. However, despite the new emphasis on debt control, observed rates of change in national debt levels are uncorrelated with debt-to-GDP ratios accumulated in 2004. Nor do we find any evidence for a reduction in the dispersion of national debt ratios after 2005. In addition, the Greek debt buildup highlights a dramatic failure of both the surveillance framework and the pre-emptive arm of the Pact (Rehn, 2010). These apparent shortcomings suggest that further amendments should be introduced in the Pact.

Our analysis is based on a simple theoretical model of a monetary union where myopic discretionary fiscal policies generate excessive debt accumulation in steady state and inefficiently delayed debt adjustment following a shock. Borrowing from the literature on monetary policy games (Svensson, 1997), we advocate the adoption of a flexible debt targeting approach. We show that, by setting a long-term debt target and by raising the political cost associated to deviations from the optimal pace of debt reversal following a shock, institutional design induces the fiscal policymaker to implement unbiased discretionary responses to shocks. Even when left with full discretion to decide the initial policy action, the fiscal policymaker will never choose an "excessive" deficit if he will then be induced to reverse it at the optimal speed.

Our results call for the de facto demise of deficit ceilings, that cause inefficient stabilisation in the face of adverse shocks but in normal times allow countries to satisfy the ceiling even if policies are relatively undisciplined. The numerical rule introduced in 2005 and requiring a uniform pace of deficits reversal (at least $0,5 \%$ of GDP per annum) should also be dismissed, as it enforces stronger discipline on those who need it less, i.e. low-debt countries. Can these arrangements be replaced by more efficient ones? It should be made clear we are not proposing just to adopt a different numerical rule for the pace of debt reversal, to be enforced as the SGP. In fact, such numerical rules are inevitably bound to introduce excessive rigidity in an uncertain macroeconomic environment. In our view, since fiscal policy decisions lie at the heart of the electoral competition in 
modern democracies, the power to discipline policymakers ultimately rests in the hands of national voters. Institutional design should therefore raise the political cost of implementing inefficient policies. This can be achieved by increasing the transparency of the decision-making process, making it easier for national voters to understand the long-term consequences of fiscal policies. In practice, we call for a substantial strengthening of the Pact pre-emptive arm, relying on clearer and more focused supervision tasks for the European Commission and for a more active role of national Parliaments whenever a disagreement arises between the Commission and a national government. Had these proposed changes been introduced in the 2005 reform, Greek policies would have been more tightly disciplined at the right time, during the fast-growth period that preceded the 2008 crisis. By contrast, we are sceptical of proposals that rely on a stronger corrective arm, such as negating the right to vote within the European Council ${ }^{1}$. In fact, the curse of the SGP is that sanctions have been unable to discipline governments in good times and have often been renegotiated or become irrelevant ex-post.

In a nutshell, the key aspects of our proposal are summarized as follows. The Commission should evaluate fiscal policies, irrespective of the current deficit size, taking into account both their short-term impact on the economy and their long-term consequences for debt accumulation. In case of disagreement with the government, the latter would then be required to report to the national Parliament, publicly motivating its decisions. This simple, transparency-enhancing proposal would raise the political cost of disregarding the Commission's advice. The European Commission would act as the "sound fiscal conscience" for national governments, and public debates in national Parliaments would trigger media coverage sufficient to provide adequate information to voters. Just as our modelling approach is inspired to the theoretical analysis of flexible inflation targeting schemes, our proposal borrows from empirical evidence on the behaviour of central banks that adopted inflation targets and carefully designed their communication strategies as a device to

\footnotetext{
${ }^{1}$ See the proposal advanced in a recent interview by the German chancellor, Angela Merkel (FT, $1^{\text {st }}$ of May 2010).
} 
strengthen their reputation and protect their independence (Mishkin and Posen, 1997; Mishkin, 2000).

The remainder of the paper is organised as follows. Section 2 presents a brief history of the SGP and discusses its evolution. Section 3 introduces new empirical evidence on the working of the (old and new) SGP. Section 4 presents the model and illustrates the design of a deficit-reversal rule that overcomes the inefficiencies generated by discretionary fiscal policy. Section 5 explains how the rule could operate in practice and discusses the implications for EMU institutional design. Section 6 concludes. 


\section{From the old to the new Pact}

The Maastricht Treaty specifies that EU fiscal policies are run nationally, following EU-wide objectives defined for a three year period by the Council of Economic and Finance Ministers (Ecofin) in the Broad Economic Policy Guidelines ${ }^{2}$ (BEPGs), and within the limits set by the SGP. The SGP design contemplates a 'preventive arm' and a 'corrective arm'. The preventive arm, under the old Pact, required countries to submit yearly Stability and Convergence Programmes (SCPs) to the European Council. National fiscal policies were then regularly scrutinised to assess their conformity with the BEPGs and with the announced SCPs. The original SGP stipulated that countries should aim for public budgets close to balance or in surplus, and set an upper bound to national deficits as a proportion of GDP (3\%), making exception only for large shocks ${ }^{3}$. Regarding the 'corrective arm', the old Pact envisaged that countries failing to comply with the BEPGs or the SCPs would be subject to censure by the other EU members, but only 'unjustified' breaches of the $3 \%$ ceiling set in the SGP were to trigger the adoption of sanctions towards a country.

A widely recognized weakness of the original SGP was that it did not take into account structural differences across countries, such as different stocks of outstanding debt, or the asymmetric effects of national fiscal policies. The preventive arm of the SGP has been amended to address the "one size fits all" issue. Each member state is now required to announce a medium-term budgetary objective (MTO). The MTO is expected to vary according to a country's own initial debt-to-GDP ratio and to potential growth. Countries with high debt and low growth potential

\footnotetext{
${ }^{2}$ The BEPGs are actually more comprehensive than the fiscal policy guidelines included in the SGP, as they also consider recommendations in areas such as structural reforms and labour market developments.

${ }^{3}$ The SGP was adopted as part of a resolution agreed by the Amsterdam European Council of 17 June 1997. The main aim of the SGP was that of strengthening the Maastricht Treaty provisions on enforcing fiscal discipline. The SGP envisaged that in the absence of the exchange rate instrument in EMU there would be a greater need for automatic fiscal stabilisers at national level and this would make it "necessary to ensure that national budgetary policies support stability oriented monetary policies". Hence the key commitment of the original SGP was to set the "... medium-term objective of budgetary positions close to balance or in surplus..." which "... will allow all Member States to deal with normal cyclical fluctuations while keeping the government deficit within the reference value of 3\% of GDP". The sanctions for breaking the 3\% upper ceiling are detailed in the Excessive Deficit Procedure (EDP) which is specified by Council Regulation 1467/97 included in the SGP. The EDP sets out that the Council, on the basis of opinions from the Commission and Ecofin within three months from the deadlines for reporting fiscal data, can declare an excessive deficit unless it is considered to be exceptional and temporary. Exceptional deficits in the original SGP were defined as resulting from: (i) an unusual event outside the control of the Member State concerned and has a major impact on the
} 
should aim at budgetary positions that are balanced or in surplus, while countries with low debt and high growth potential are allowed MTOs of up to -1\% of GDP (European Commission, 2005). The adjustment path towards the MTO is measured on a cyclically-adjusted basis, taking into account major structural reforms, and subject to a benchmark adjustment of $0.5 \%$ per year on average over the cycle, with stronger adjustment in good times. Thus, in contrast to the old Pact, the 'preventive arm' of the new Pact recognizes the importance of structural differences across countries and allows for differentiated budgetary objectives. Nevertheless, the new SGP reverts to the "one size fits all" policy when recommending a benchmark adjustment toward MTOs of $0.5 \%$ GDP per year for all countries.

The 'corrective' arm of the old SGP was criticized for imposing unduly restrictive deficit ceilings in bad times. The new regulations maintain a deficit ceiling at 3\% of GDP but broaden the circumstances when a breach of the 3\% ceiling does not trigger an Excessive Deficit Procedure. In essence 'exceptional circumstances' can be invoked in all recessions and when growth is low relative to trend, not just in case of severe recessions ${ }^{4}$. Several contributions pointed out that the old ‘corrective arm' could not discipline procyclical fiscal in good times (Bean, 1998; CESifo, 2002; Canzoneri and Diba, 2001). Under the new Pact, the Commission is expected to give policy advice directly (i.e. not mediated by the Council) to countries deviating from their MTO or failing to implement the minimum adjustment effort of $0.5 \%$ of GDP, in bad as well as good times. Moreover, the Commission is allowed to bring to the attention of the Council not only countries at risk of breaching the $3 \%$ ceiling but also countries failing to comply with preventive rules of the new Pact. However, as in the old Pact, there are no costs for governments non-complying with the prescriptions of the preventive rules of the SGP.

financial position of the general government; or (ii) from a severe economic downturn (if there is an annual fall of real GDP of at least $2 \%$ ).

${ }^{4}$ See Artis and Onorante (2006) for a critical analysis. 


\section{EMU fiscal policies in practice}

There seems to be a general consensus that "a counter-cyclical response of discretionary fiscal policies seems to be the exception rather than the rule." (European Commission, 2008, p. 20). Golinelli and Momigliano (2008) report that studies based on ex-post data suggest a shift from a pro-cyclical ante-Maastricht stance to an a-cyclical post-Maastricht stance. Real time data support a more counter-cyclical view of the discretionary fiscal policy, suggesting that pro- or a-cyclical effects were unintentional and due to poor measurement and forecasting of the cycle. Still, independently of the data source, Golinelli and Momigliano (2008) find that "a slight tendency towards a more pro-cyclical (or less counter-cyclical) behaviour emerges over time.” (p. 21). Turrini (2008) investigates the determinants of the change in the cyclically adjusted primary balance (CAPB) to the output gap over the period 1980-2005. He finds that CAPB variations are not sensitive to variations in output. Further, the a-cyclicality of the CAPB is due to a composition effect resulting from countercyclical tax revenues and procyclical expenditures. Estimates of changes in CAPB run separately for good and bad times reveal a pro-cyclical bias in good times and no bias in bad times. The pro-cyclical bias in good times is due to the expenditures component of the CAPB. The above results are confirmed when the 1980-2005 interval is split into sub-periods and separate regressions are run for the post-Maastricht years. Following the adoption of the SGP, the fiscal stance appears to be less pro-cyclical in bad times, but "no significant impact of the EU fiscal framework is found on the average fiscal stance in good times." (p. 21). Annett (2006) shows that the Maastricht discipline effect seems to vanish once countries gain EMU membership. The improvement of the overall balance for EMU countries since the adoption of the SGP actually masks unchanged (small countries) or deteriorating (large countries) cyclically adjusted primary balances with respect to the early post-Maastricht years. Similar results are found in Von Hagen (2005), who confirms that fiscal discipline prevailed in the run-up to EMU, but was abandoned thereafter. 
In the following we present simple but stark evidence ${ }^{5}$ supporting the view that the SGP fails to discipline fiscal policymakers when they most need it, and vice versa. Unlike the studies quoted above, we do not consider the pre-1999 period. We discuss, instead, the apparent effects of the 2005 reform of the Pact. We shall focus on three key questions: $i$ ) do we observe convergence of debt-to-GDP ratios towards the $60 \%$ objective? $i$ ) did national policies generate an appropriate countercyclical fiscal stance at the EMU level? iii) did the 2005 reform improve matters?

Table 1 shows that public debt declined in the Euro area over the years $1999-2007^{6}$, while dispersion (as measured by the standard deviation - SD) of national debt/GDP ratios exhibits a modest reduction, which occurred only in the first few years. Table 1 also shows the evolution of the output gap (YGAP).

Table 1

\begin{tabular}{|l|r|r|r|r|r|r|r|r|r|}
\hline Euro Area & $\mathbf{1 9 9 9}$ & $\mathbf{2 0 0 0}$ & $\mathbf{2 0 0 1}$ & $\mathbf{2 0 0 2}$ & $\mathbf{2 0 0 3}$ & $\mathbf{2 0 0 4}$ & $\mathbf{2 0 0 5}$ & $\mathbf{2 0 0 6}$ & $\mathbf{2 0 0 7}$ \\
\hline \%Debt/GDP & 62.7 & 59.2 & 58.2 & 57.5 & 57.6 & 57.3 & 57.2 & 55.5 & 53.6 \\
\hline SD & & & & & & & & & \\
Debt/GDP & 30.1 & 29.1 & 29.1 & 28.4 & 27.6 & 27.2 & 28.0 & 28.1 & 27.4 \\
\hline YGAP & 1.1 & 2.7 & 1.8 & 0.5 & -1.0 & -1.1 & -1.2 & -0.5 & -0.1 \\
\hline
\end{tabular}

Figure 1 shows that four countries actually increased the stock of debt, and the observed pace of debt reduction for the remaining ones seems unrelated to initial debt ratios. Furthermore, no difference emerges for the post 2004 sample (Figure 2). Indeed, the dispersion of national debt ratios increases if one neglects countries that exploited a relatively favourable initial position to run a relatively looser fiscal stance.

\footnotetext{
${ }^{5}$ We use data from OECD Economic Outlook. As for the EMU countries, we consider Austria, Belgium, Finland, France, Germany, Ireland, Italy, Luxembourg, Netherlands, Portugal and Spain, i.e. the only countries covered by the SGP since its adoption.

${ }^{6}$ We deliberately omit year 2008 from our Debt/GDP series. At the outset of the financial crisis, public interventions in the ailing banking sector consisted in the acquisition of financial assets recorded "below the line" and thus affecting debt (but not deficit). See Public Finances in EMU (2009), p. 2.
} 
Fig.1 EMU countries 1999-2007

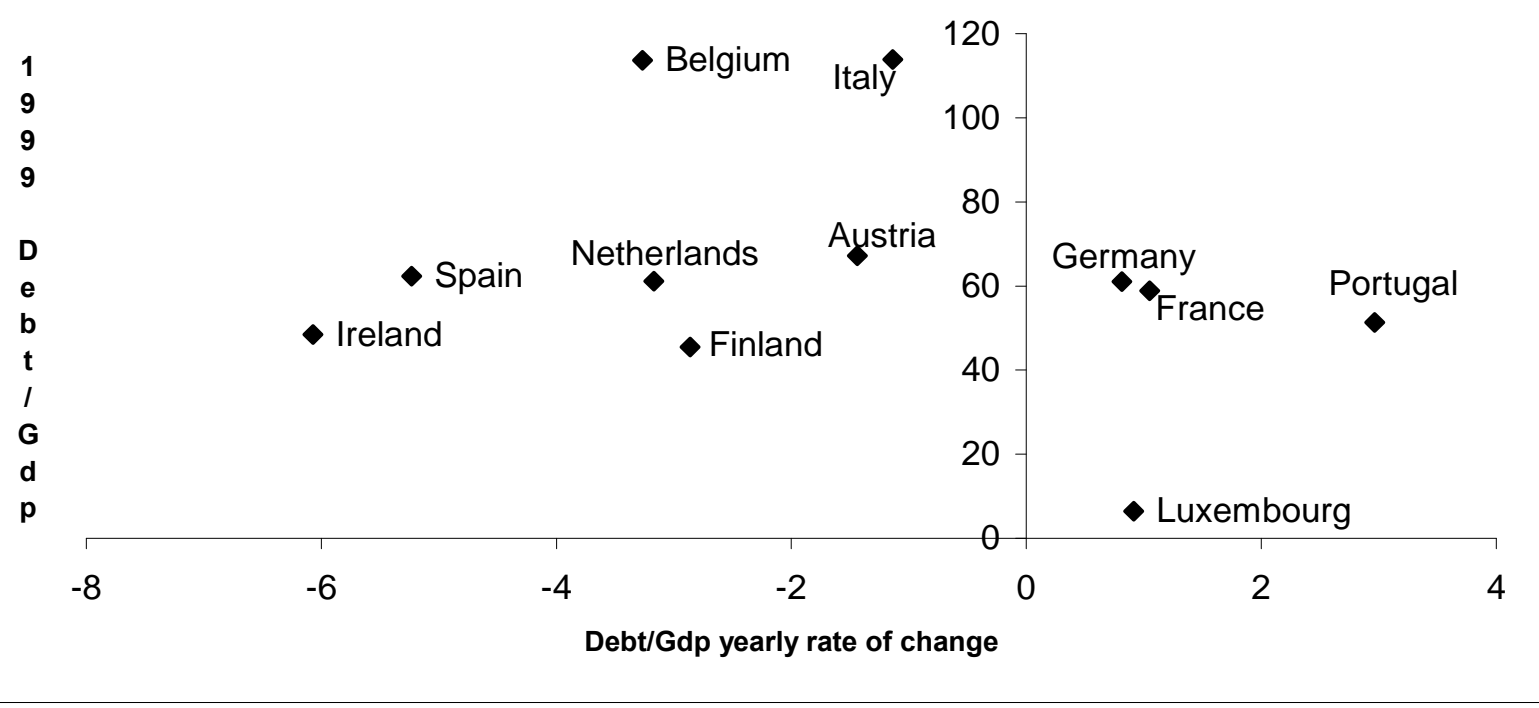

Fig.2 EMU countries 2004-2007

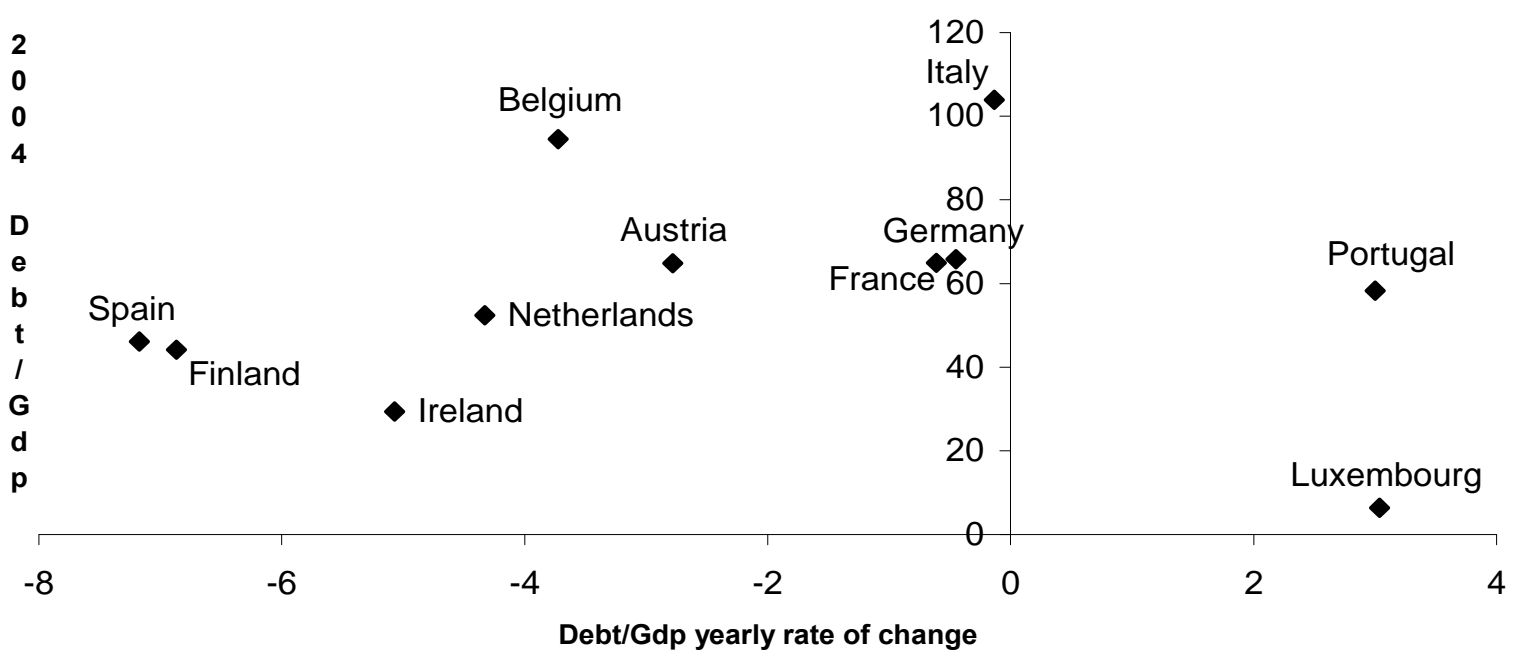


Figure 3 vividly illustrates the faltering performance of fiscal policies under the SGP regime. The change in the cyclically-adjusted balance-to-GDP ratios (CAPB) is in the negative when favourable cyclical conditions (output gap - YGAP) prevail, while discretionary fiscal policy tightens only when adverse cyclical conditions bring the actual deficit close the $3 \%$ ceiling.

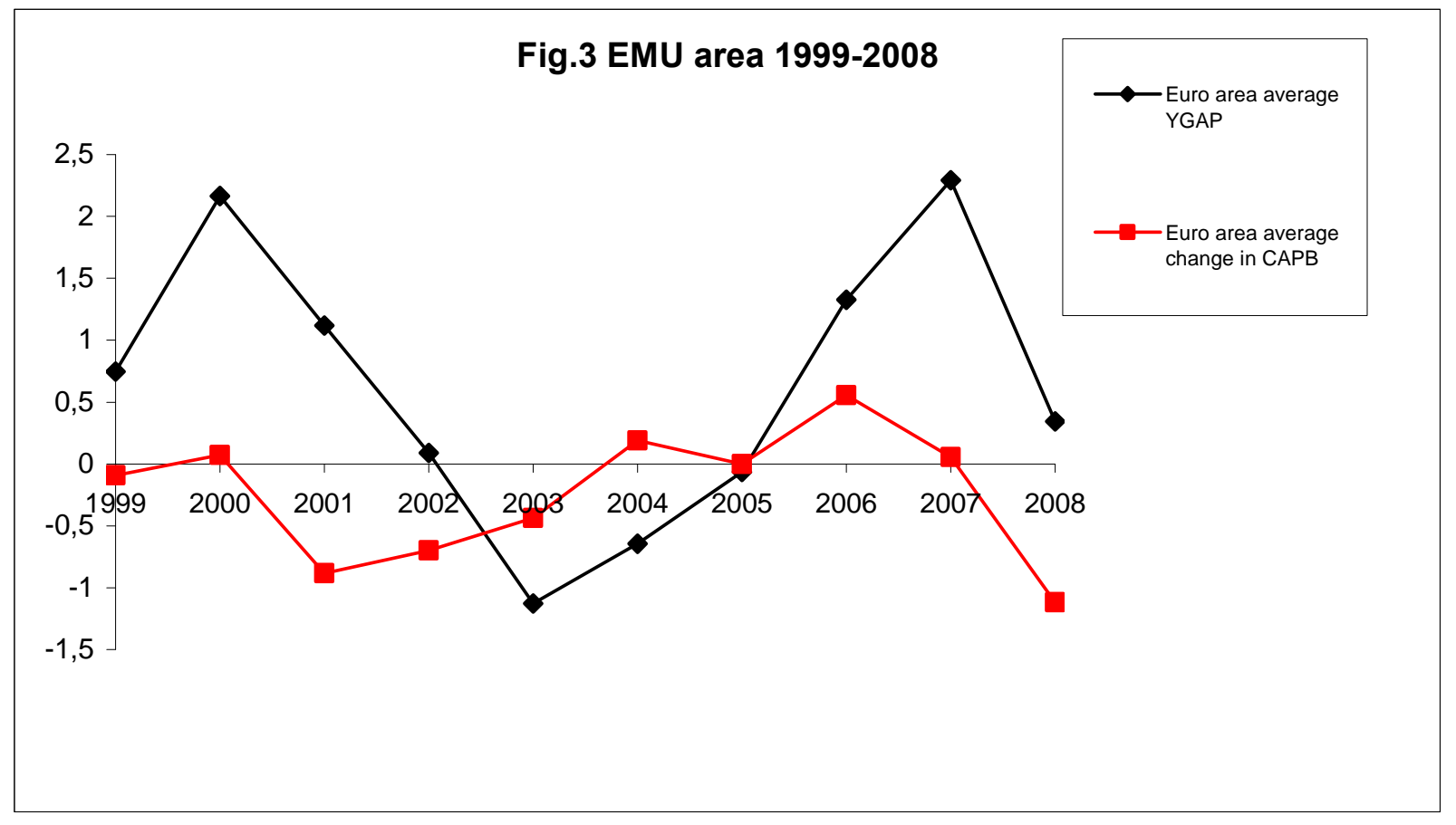

A completely different picture emerges from the US data (Figure 4).

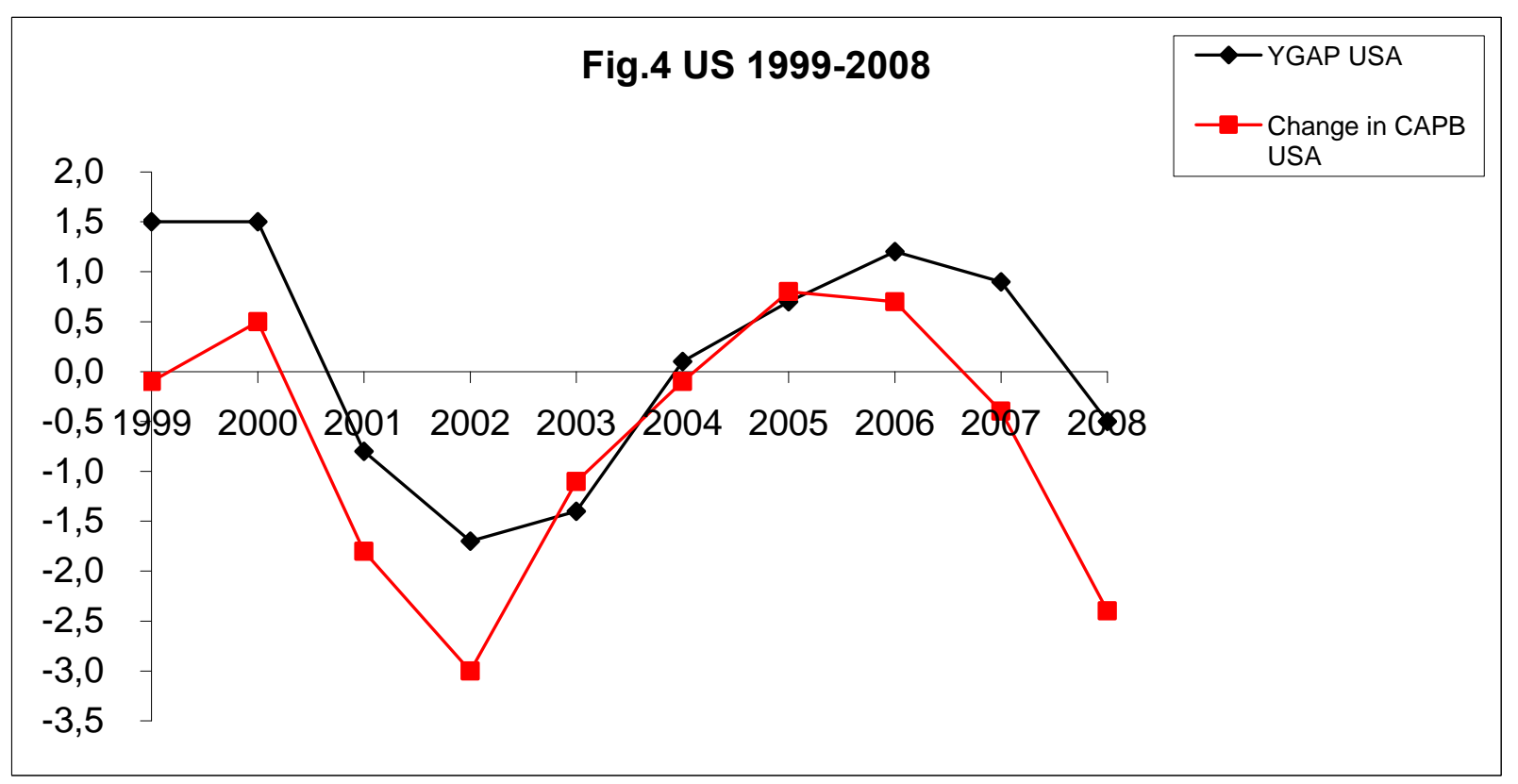


In Figure 5 and 6 respectively, we plot scattered diagrams for YGAP and changes in CAPB $(\triangle \mathrm{CAPB})$ in the EMU area and in the US.
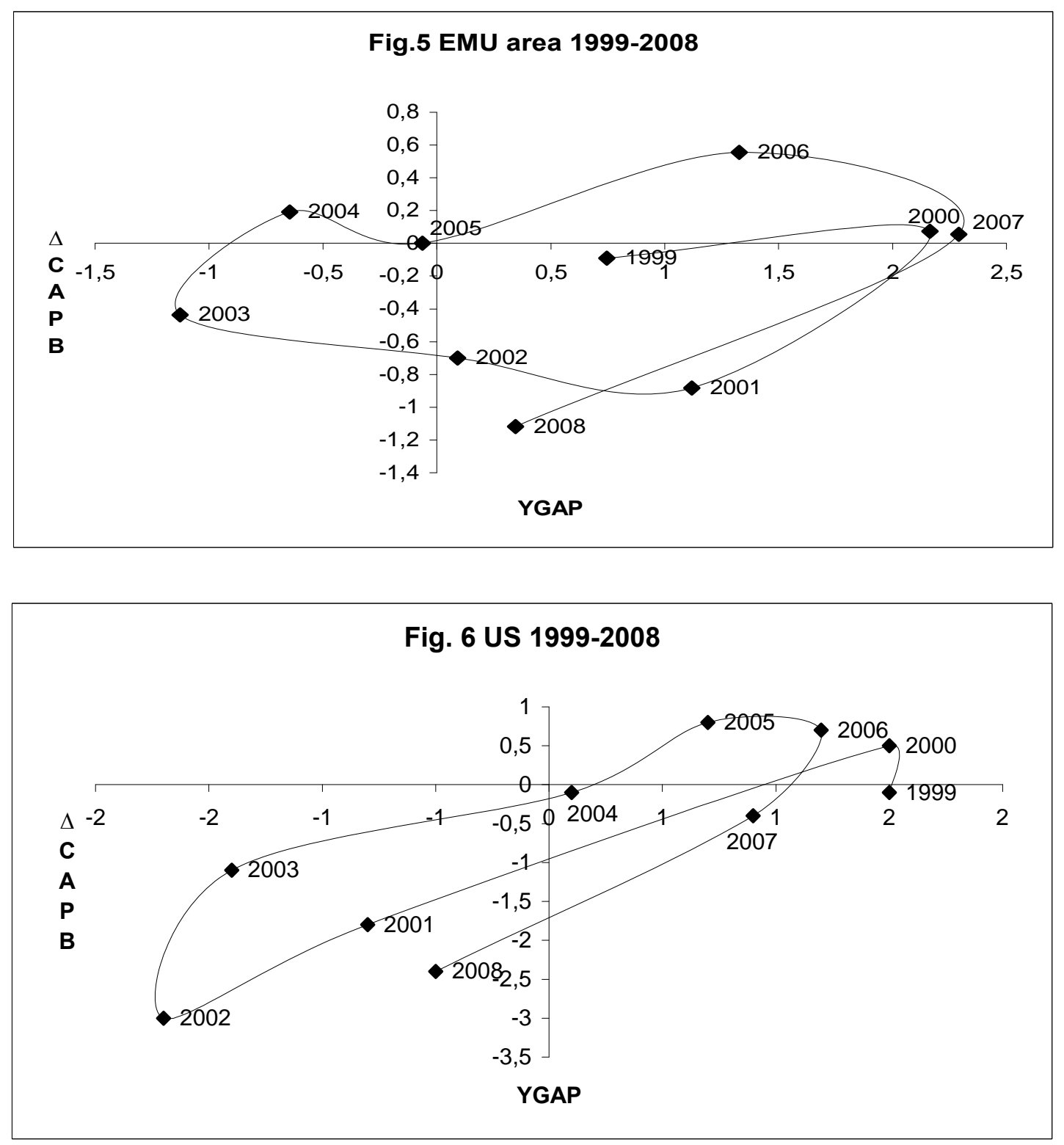

US observations signal that adverse cyclical conditions are associated with falling CAPBs and (in several occasions) vice versa. The Euro area pairs form instead a "cloud": very similar changes in cyclically adjusted balances are associated with markedly different cyclical conditions. Moreover, both US and EMU fiscal policies are relatively procyclical in good times, but only in the Euro area we observe fiscal contractions in coincidence with negative output gaps. We replicated Figure 6 for each EMU country and found that the apparent lack of correlation between fiscal stance and cyclical conditions is a common feature. This is summarized in Figure 7. 
Fig. 7 EMU countries 1999-2008

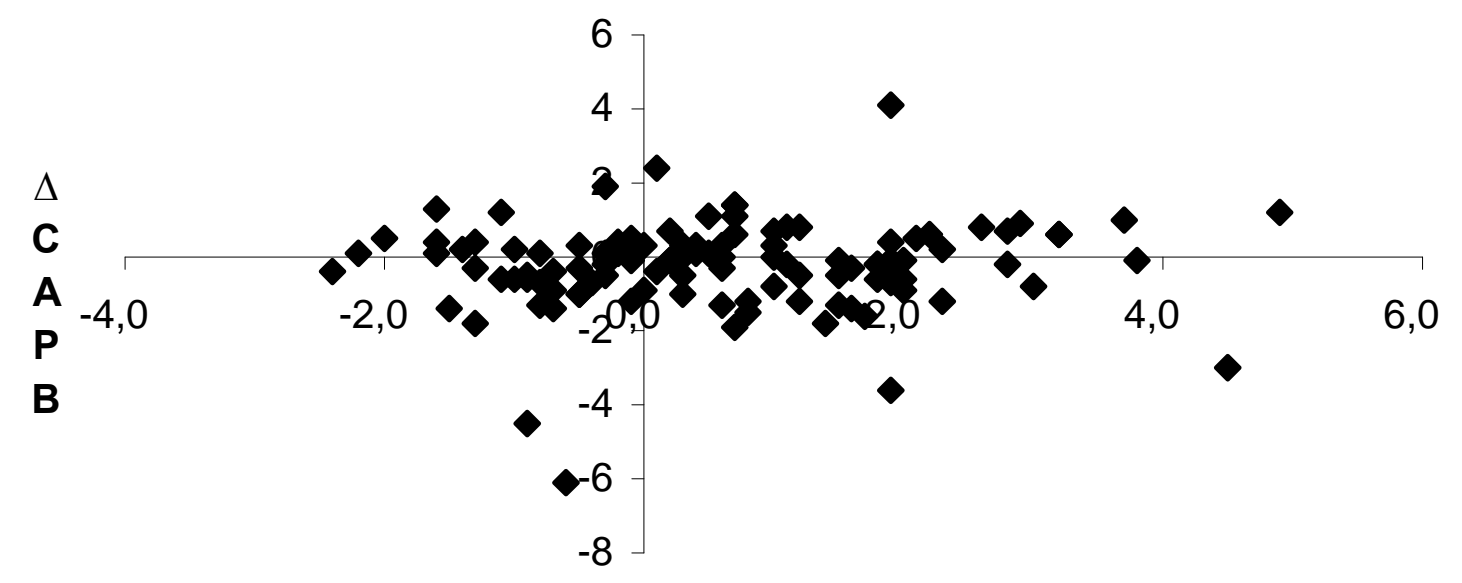

YGAP

Splitting the sample to account for the 2005 SGP reform (Figure 8 and 9) highlights that up to 2004 the procyclicality of fiscal policies is mainly characterized by the association of positive output gaps and deteriorating fiscal stances. After 2005 this situation is reversed: we frequently observe combinations of negative output gaps and contractionary fiscal stimuli.

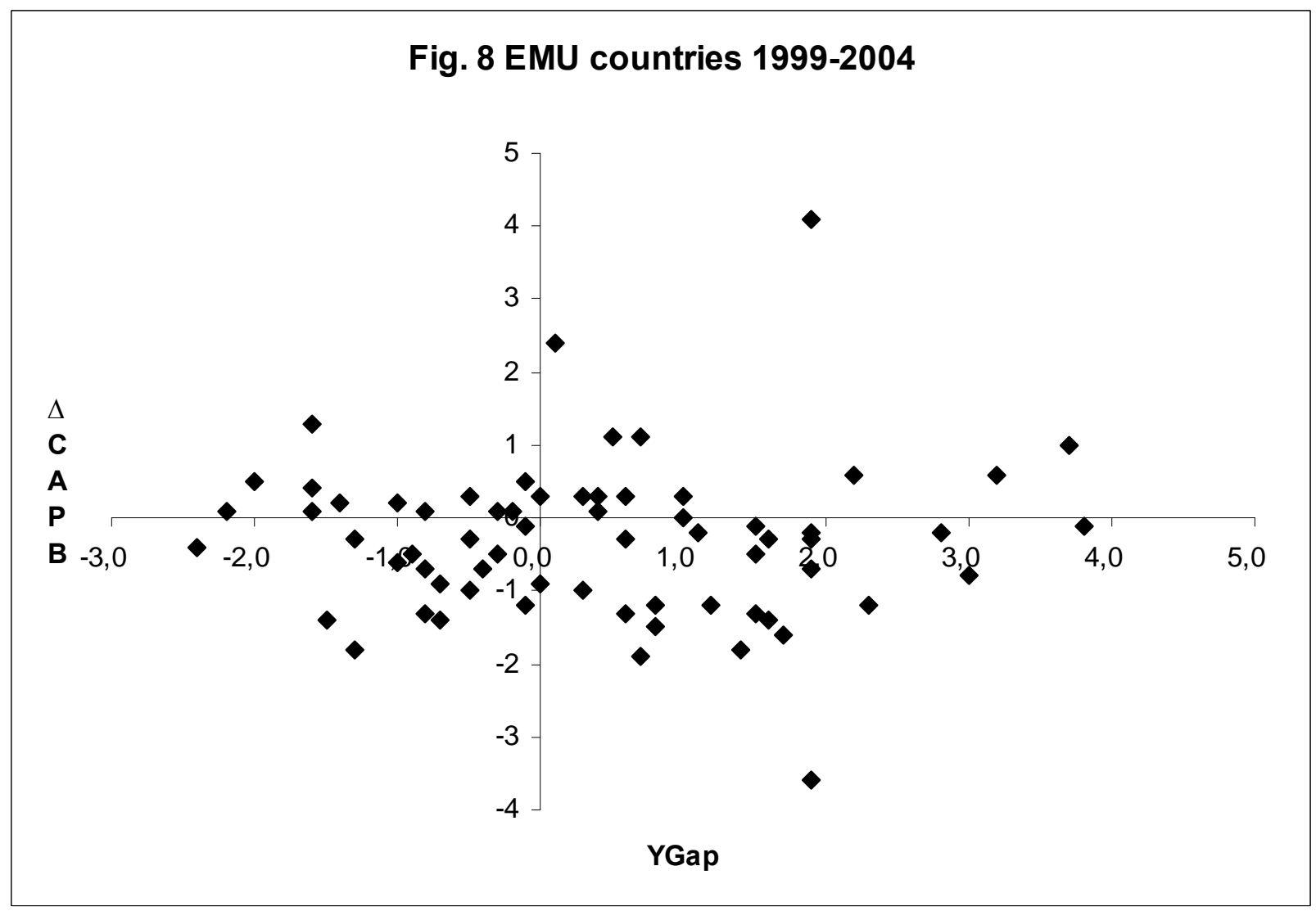




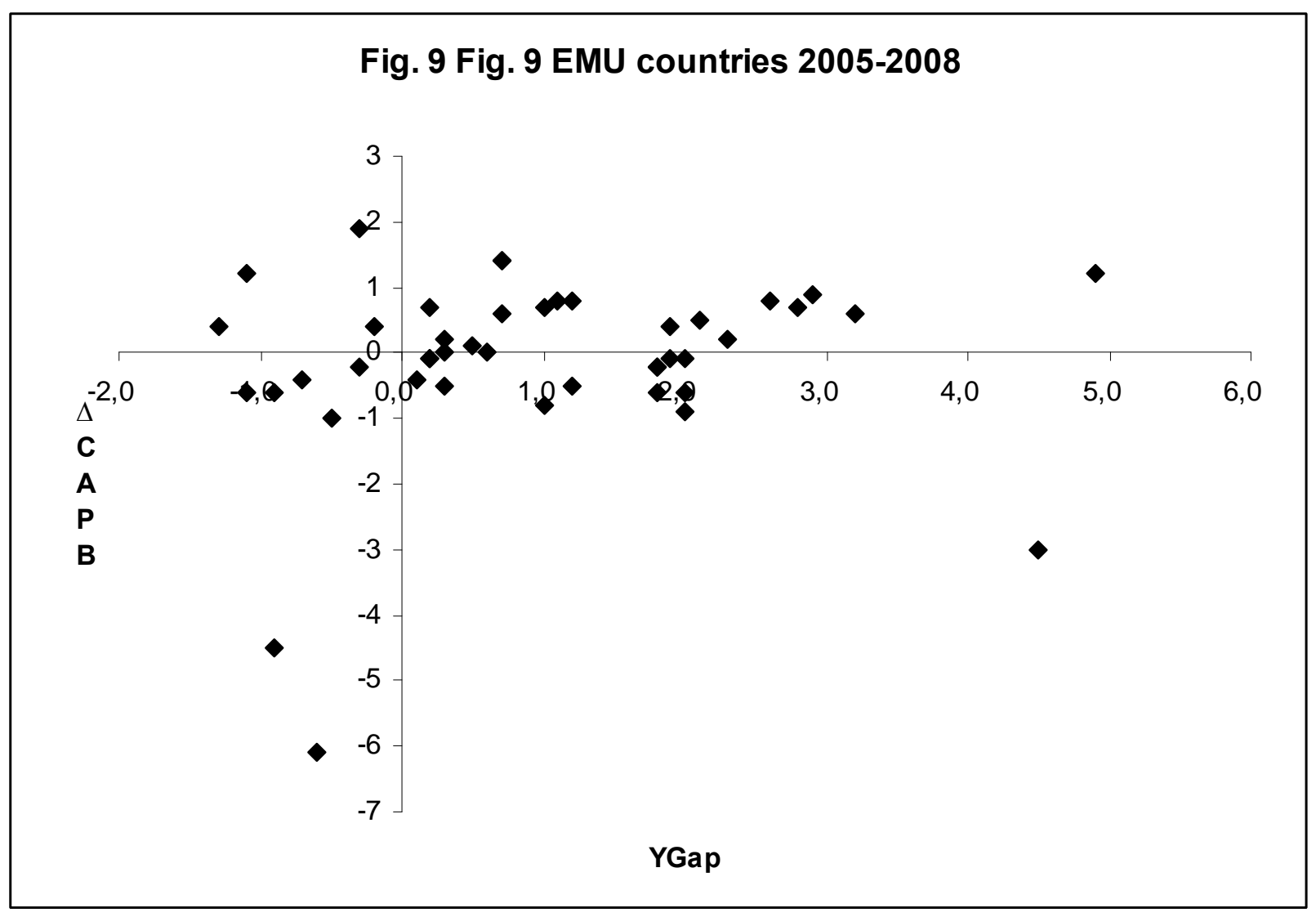

This is broadly in line with the observed time series of the EMU aggregate fiscal stance. In the first years of EMU, governments exploited the SGP apparent ineffectiveness under favourable economic conditions and were then forced to reverse their fiscal stances when growth perspectives deteriorated. It is interesting to observe that OECD countries which are non-EMU members did implement procyclical policies in good times but seldom chose to implement contractionary policies when the output gap turned negative (Figure 10) ${ }^{7}$.

\footnotetext{
${ }^{7}$ We removed from our data set the observation for Iceland in 2008 as the country CAPB fell by $18.4 \%$ with respect to 2007, many orders of magnitude larger than the average change across OECD-non EMU countries and to be ascribed entirely to the attempt to prevent the melting of the Icelandic economy.
} 


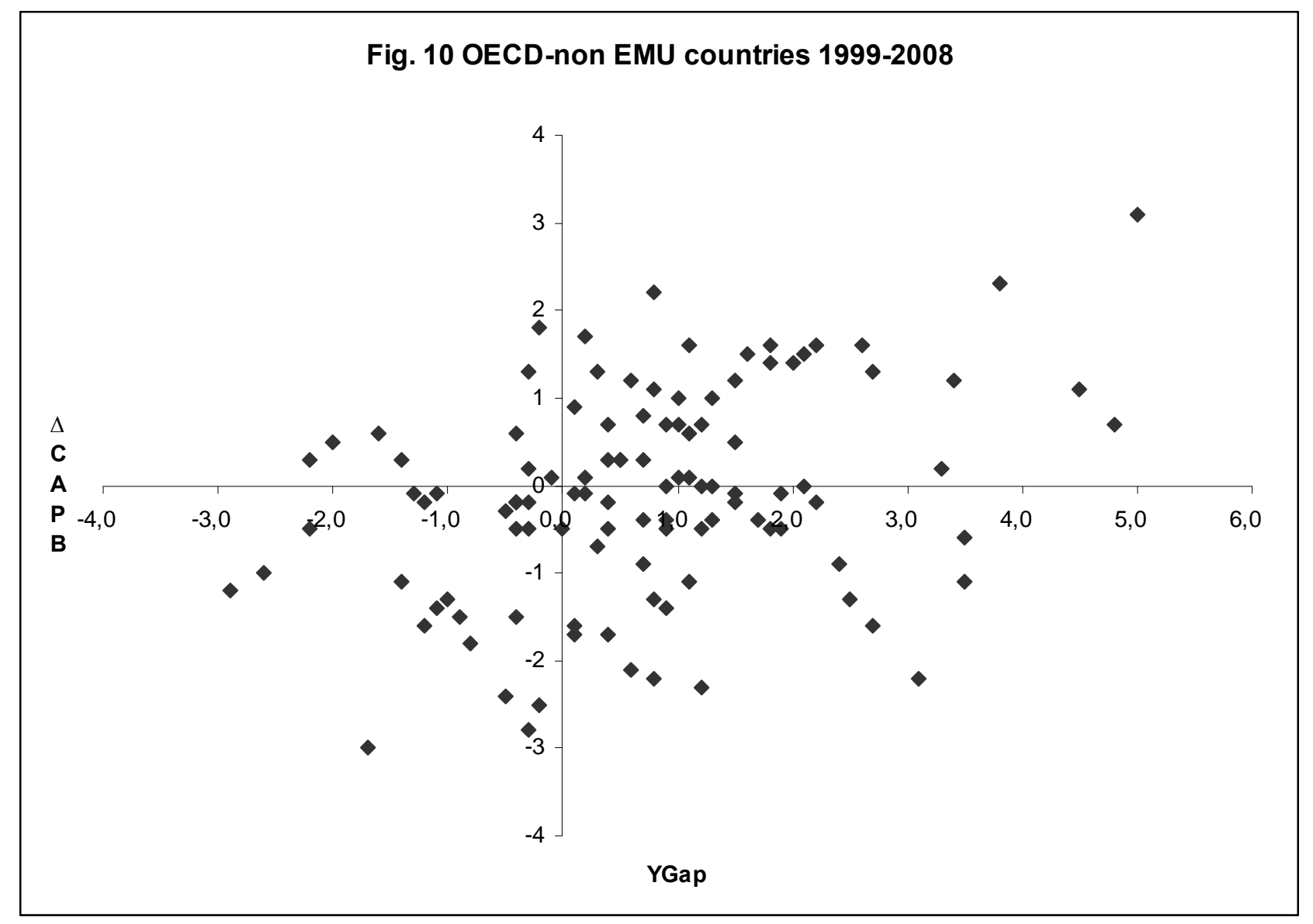

In Table 2 we present some basic correlations, confirming this analysis. In fact we find evidence of a consistently countercyclical fiscal policy only for the US and for OECD non-EMU countries.

Table 2

\begin{tabular}{|l|c|}
\hline Debt-GDP ratio yearly rate of change 1999-2007; 1999 Debt-GDP ratio & -0.21 \\
\hline $\begin{array}{l}\text { Debt-GDP ratio yearly rate of change 2004-2007; 2004 Debt-GDP ratio } \\
\text { EMU area average change in CAPB 1999-2008; EMU area average YGAP } \\
\text { 1999-2008 }\end{array}$ & 0.008 \\
\hline USA average change in CAPB 1999-2008; USA average YGAP 1999-2008 & $0.83^{* * *}$ \\
\hline EMU countries: $\triangle$ CAPB 1999-2008; YGAP 1999-2008 & 0.08 \\
\hline EMU countries: $\triangle$ CAPB 1999-2004; YGAP1999-2004 & -0.01 \\
\hline EMU countries: $\triangle$ CAPB 2005-2008; YGAP 2005-2008 & 0.16 \\
\hline OECD-non EMU countries: $\triangle$ CAPB 1999-2008; YGAP 1999-2008 & $0.34^{* * *}$ \\
\hline
\end{tabular}

$* * *=$ significant at the $1 \%$ level 
The key results in this section can be summarized as follows. Since the adoption of the SGP, the debt-to-GDP ratio has fallen on average, but significant differences still exist across countries. Furthermore, this reduction has not been driven by the goal of achieving the $60 \%$ target. In fact, variations in the stock of debt are independent of its initial level. This pattern persists after 2005, despite the new SGP emphasis on national MTOs and debt correction objectives. EMU countries are prone to a procyclical bias in good times, just like other countries which are not subject to the SGP. By contrast, EMU countries exhibit an additional procyclical bias in bad times, when the deficit ceiling is more likely to bite. We also find that this latter effect occurred after 2004, in spite of the relative flexibility introduced in the new Pact.

\section{Theoretical underpinnings of a flexible debt targeting approach}

We consider here a version of Jensen's (1994) model of debt accumulation, extended to account for both supply shocks and the loss of monetary sovereignty that characterizes EMU membership. The monetary union is formed by $n$ identical economies ${ }^{8}$. In country $i$, the supply function is given by:

$$
y_{i, t}=-\tau_{i, t}+\varepsilon_{i, t}+\pi_{t}-E\left(\pi_{t}\right)
$$

where output deviations from the socially optimal level, $y_{i, t}$, depend on distortionary taxes, $\tau_{i, t}$, an idiosyncratic shock, $\varepsilon_{i, t}$, i.i.d. with zero mean and variance $\sigma_{\varepsilon}^{2}$, inflation surprises $\pi_{t}-E\left(\pi_{t}\right)$, where $\pi_{t}$ is the inflation rate chosen by the common central bank and $E\left(\pi_{t}\right)$ is its rational expectation. As it is typical of time-inconsistency models, nominal wages are pre-determined and incorporate inflation expectations.

Government $i$ 's budget constraint can be written as ${ }^{9}$ :

$$
D_{i, t}=(1+r) D_{i, t-1}+G_{i, t}-\tau_{i, t}
$$

\footnotetext{
${ }^{8}$ All variables are in logs.

${ }^{9}$ Equation (2) is a logarithmic approximation to the government budget constraint, where all variables are normalised by non-distortionary output, as in Beetsma and Bovenberg (1997).
} 
where $D_{i, t}$ denotes the stock of government debt at the end of period $t$ and $r$ is the real rate of interest ${ }^{10}$.

\subsection{The social welfare function and the optimal fiscal policy}

In each country, the social welfare function is ${ }^{11}$

$$
\begin{aligned}
& W_{i, t}=\sum_{s=0}^{\infty}\left(\beta^{*}\right)^{s} L_{i, t+s}^{*} \\
& L_{i, t+s}^{*}=\frac{1}{2}\left[\left(y_{i, t+s}\right)^{2}+k_{1}\left(G_{i, t+s}-\widetilde{G}^{*}\right)^{2}+k_{2}\left(\pi_{t+s}-\tilde{\pi}^{*}\right)^{2}\right]
\end{aligned}
$$

where $\beta^{*}$ is the discount factor, $\left(G_{i, t+s}-\widetilde{G}^{*}\right)$ and $\left(\pi_{t+s}-\tilde{\pi}^{*}\right)$ denote public expenditure and inflation deviations from the socially optimal levels respectively. We assume full central bank commitment an inflation target. As shown in Svensson (1997), the choice of an appropriate inflation target completely removes the inflation bias typical of time-inconsistency models. The combination of idiosyncratic shocks and inflation targeting implies that $\pi_{t+s}=\tilde{\pi}^{*} \forall s$ and allows to sharpen the analysis of fiscal policy ${ }^{12}$.

We can now characterize the solutions to the fiscal policy problem when the policymaker is committed to optimize the social welfare function. To solve the model we need an intra-temporal condition for taxes and an inter-temporal condition for debt-financed choice of public expenditures. Taxes will be set to equate the marginal benefits of a tax-financed increase in expenditures to the marginal costs of higher taxes, i.e. the ensuing output distortions:

$$
\tau_{i, t}=-k_{1} g_{i, t}+\varepsilon_{i, t}
$$

\footnotetext{
${ }^{10}$ To limit analytical complexity, we assume that $r$ is constant and government debt is fully indexed, as in Jensen (1994) and Beetsma and Bovenberg (1997). The r.h.s. term of eq. (2) does not include seigniorage revenues. In modern economies the limited amount of domestic money holdings relative to GDP severely constrains the possibility of raising anticipated seigniorage revenues. For sake of simplicity we therefore neglect this component of the budget constraint.

${ }^{11}$ Quadratic formulations of the loss function may look unduly restrictive. However (3) may be viewed as an acceptable approximation to a more general utility function. With this justification, the policymaker's loss functions is assumed to be quadratic even in models that explicitly describe the representative agent's preferences (Rotemberg and Woodford, 1997, 1999; Dixit and Lambertini, 2000).

${ }^{12}$ By definition, the common central bank will not react to idiosyncratic shocks.
} 
where $g_{i, t}=\left(G_{i, t}-\widetilde{G}^{*}\right)$. As in Jensen (1994), taxes increase with the public expenditure gap $g_{i, t}$ and fall when shocks are negative, in order to smooth output.

The first order condition for debt policy in period $t$ is:

$$
k_{1} g_{i, t}=\beta^{*} k_{1}(1+r) E_{t}\left(g_{i, t+1}\right)
$$

As shown in Jensen (1994), the policymaker weighs the marginal benefit of a debt-financed increase in $g_{i, t}$ against the marginal loss from the expected reduction in $E_{t}\left(g_{i, t+1}\right)$. In this case, reinvested budget surpluses build up a stock of negative debt in steady state, earning the income necessary to fully finance the desired level of expenditures, $\widetilde{G}^{*}$. As a result, tax distortions disappear.

\subsection{The fiscal policy problem under discretion}

We assume that national policymakers' objective functions are distorted:

$$
\begin{aligned}
& W_{i, t}=\sum_{s=0}^{\infty} \beta^{s} L_{t+s}^{G^{i}} \\
& L_{t+s}^{G^{i}}=\frac{1}{2}\left[\left(y_{i, t+s}\right)^{2}+k_{1}\left(G_{i, t+s}-\widetilde{G}\right)^{2}+k_{3}\left(D_{i, t+s}-\widetilde{D}\right)^{2}\right]
\end{aligned}
$$

where $\beta$ is the discount factor and $\left(D_{i, t+s}-\widetilde{D}\right)$ denotes debt deviations from desired level. From a comparison with (3), it is easy to see that fiscal policymaker's preferences substantially differ from the social welfare function. The first difference concerns the discount factor. The literature on fiscal policy games has pointed out that political incentives induce governments to postpone fiscal adjustment, causing excessive reliance on debt to finance expenditures and excessive accumulation of debt in steady state. To capture this effect, we assume that the government discount factor is inefficiently low ${ }^{13}$, i.e. $\beta<\beta^{*}$ (Beetsma and Bovenberg, 1997). The second difference concerns the absence of inflation from (6) $)^{14}$, which would be redundant because in our framework inflation is

\footnotetext{
${ }^{13}$ A policymaker's discount factor may vary over time. In particular it may be closer to the social optimum at the beginning rather than at the end of her term in office. Allowing for this possibility would not alter the conclusions of the model.

${ }^{14}$ In models of EMU fiscal policy it is sometimes claimed that national governments are not concerned with the inflation rate, whose control is under the exclusive responsibility of the central bank (Buti et al. 2001). None of our
} 
exogenous. The third difference is the inclusion of a quadratic term in debt, as in Tabellini (1986). It is intuitively obvious that Jensen's (1994) result cannot hold if the policymaker pursues a nonnegative debt target, as in (6). The persistence of excessive debt levels, which cause steady-state tax distortions, has several explanations ${ }^{15}$. It may be seen as the consequence of electoral competition when policymakers disagree about the composition or the level of public expenditures (Alesina and Tabellini, 1989; Persson and Svensson, 1989). Another strand of literature emphasises the role of intergenerational conflict (Cukierman and Meltzer, 1989). A non-distortionary steady-state equilibrium implies that current generations bear the costs of running budget surpluses in order to relieve future generations from the burden of distortionary taxation. This outcome might hold in a world where generations are altruistically linked through bequests, so that the intertemporal distribution of deficits only responds to efficiency considerations. Yet fiscal policy may be biased towards excessive debt accumulation if some individuals are bequest constrained, i.e. they would like to borrow from future generations leaving negative bequests. In fact, public debt policy allows bequest-constrained individuals to raise their consumption levels at the expenses of future generations. This happens because deficits are used to subsidise the consumption of bequestconstrained agents, whereas debt will partly substitute capital in the portfolio of non bequestconstrained individuals. Thus, the term $k_{3}\left(D_{i, t+s}-\widetilde{D}\right)$ may be interpreted as follows: $\left.i\right)$ the target $\widetilde{D}$ defines the level of debt which would emerge if non-distortionary taxes were available in a world where bequest-constrained individuals affect politico-economic equilibria; ii) $k_{3}$ represents the political cost of tolerating debt deviations from $\widetilde{D}^{16}$.

results would be significantly affected if we allowed for an endogenous inflation rate (this proof is available from the authors on request).

${ }^{15}$ For a survey see Alesina and Perotti (1995).

${ }^{16}$ This is an admittedly rough-and-ready way to incorporate adverse political incentives into the policymaker's behaviour and to obtain the persistence of inefficient tax distortions in steady-state equilibrium. We adopt it because extending the Cukierman and Meltzer framework to account for distortionary taxation and time-inconsistency in monetary policy would quickly render their model unsuitable for the analysis of monetary regimes. By the same token, explicitly modelling electoral incentives as in Alesina and Tabellini (1989) would unnecessarily complicate the algebra. 
Under discretion, the fiscal policymaker will set taxes according to (4). By contrast, the first order condition for debt policy in period $t$ is:

$$
k_{1} g_{i, t}+k_{3}\left(D_{i, t}-\widetilde{D}\right)=\beta k_{1}(1+r) E_{t}\left(g_{i, t+1}\right)
$$

In addition to the trade-off between current and future expenditures, the fiscal policymaker now takes into account the marginal cost of deviating from $\widetilde{D}$. It is easy to see that, relative to the social optimum (5), the terms $k_{3}\left(D_{i, t}-\widetilde{D}\right)$ and $\beta$ distort the choice of debt levels in each period.

The model solution under $(7)^{17}$ shows that concern for a distorted debt target unambiguously biases national fiscal policies towards inefficient debt accumulation in steady state. Conclusions about discretionary responses to shocks are less clear cut. The more short-sighted governments are relative to a social planner $\left(\beta<\beta^{*}\right)$, the stronger is the deficit sensitivity to shocks and the greater is the (inefficient) persistence of debt deviations from steady state. By contrast, the policymaker's reluctance to tolerate debt deviations from the objective works in the opposite direction: the larger is coefficient $k_{3}$, the less sensitive to shocks is the deficit.

\subsection{The fiscal policy problem under a debt targeting rule}

Can institutional design provide a solution? To see this we assume that a commitment technology exists such that a debt target $\widetilde{D}^{T}$ may be imposed on the fiscal policymaker and that any discretionary choice of debt-financed public expenditures must be reversed in the future at the rate $\alpha^{*}(1+r)$. In this case, the inter-temporal first order condition for debt becomes:

$$
k_{1} g_{i, t}+k_{3}\left(D_{i, t}-\widetilde{D}^{T}\right)=\beta k_{1} E_{t}\left(g_{i, t+1}\right) \alpha^{*}(1+r)
$$

The model solution under $(8)^{18}$ shows that the pair $\widetilde{D}^{T}=-\frac{\widetilde{G}}{r}, \alpha^{*}=\frac{\beta^{*}}{\beta}-\frac{k_{3}}{k_{1}} \frac{\left(1+k_{1}\right)}{(1+r)^{2} \beta}$ allows to replicate the social optimum, eliminating distortions. In this case, deficit dynamics take the following form:

\footnotetext{
${ }^{17}$ See the Appendix.

${ }^{18}$ See the Appendix.
} 


$$
D_{t}-D_{t-1}=-\left(\frac{\beta^{*}(1+r)-1}{\beta^{*}(1+r)}\right)\left(D_{t-1}-D_{s s}\right)-\frac{\varepsilon_{t}}{\beta^{*}(1+r)^{2}-1}
$$

where $D_{s s}$ is steady state debt. Observe that $\beta^{*}(1+r)>1$ is a necessary and sufficient stability condition, as in Jensen (1994). The budget deficit is therefore decomposed into a cyclical component (deficits are inversely related to shocks) and a structural component, i.e. a negative feedback on accumulated debt deviation from the steady state.

The theoretical model therefore provides an unambiguous conclusion: by inducing the appropriate debt target and pace of debt reversal, institutional design drives the fiscal policymaker to implement unbiased discretionary policies. Even when left with full discretion about the initial response to shocks, the fiscal policymaker will never choose an "excessive" deficit if he anticipates an appropriate cost in terms of future deficit reversal. Furthermore, the model has a clear policy prescription, linking national deficits to country-specific cyclical conditions and to country-specific accumulation of debt. It is interesting to see that the social optimum would obtain under a simple deficit reversal rule, imposing that any discretionary deficit-financed increase in expenditures be reversed at a pre-determined speed. In the next section we shall discuss how, in principle, EMU institutions could deliver that.

\section{Turning the SGP into a flexible debt targeting regime}

Taken at face value, the new SGP is consistent with our proposal of endorsing a long-term debt target. In fact, the SGP requirement of a budget close to balance implies a very small (possibly zero) steady state debt-to-GDP ratio. In addition, the new Pact requires countries to specify their medium-term budgetary objectives taking into account past debt and potential growth rates. Our model provides a theoretical underpinning for this choice. In fact, by solving forward equation (9) one can project the initial shock into a sequence of optimal deficits. Furthermore, the greater flexibility in the face of cyclical downturns envisaged by the new 'corrective arm' is certainly welcome. By contrast, the empirical evidence presented in section 3 justifies scepticism. The new, 
more flexible Pact is associated with procyclical policies that reduced debt when business cycle conditions were deteriorating. Perhaps this could be justified as the hard price to be paid after the profligacy of the early EMU years. More difficult to rationalize is the virtual non-convergence of national debt ratios observed in this period. Despite the 2005 reform, the SGP has had relative success in enforcing discipline when flexibility was desirable, and vice versa. What is missing in the new SGP?

As a matter of fact, the new Pact is still open to criticisms. First, the procedure for identifying "shocks" leaves excessive discretion to national governments who in the past have often disagreed with the European Commission on business cycle and budget deficit. The European Council turned down a proposal that all forecasts be provided by the Commission, and the current arrangement allows countries to use their own forecasts simply requiring them to "to explain in details divergences with respect to the Commission forecasts" (Buti et al, 2005, p. 21). Such a provision is unlikely to remove the observed "optimistic bias" of national forecasts (Strauch, Hallberg and von Hagen, 2004), which obviously contributed to slow down the speed of debt correction. Second, the adoption of an identical benchmark adjustment for accumulated deficit deviations from the MTO brings back the much criticized "one size fits all" approach that shaped the old SGP. Third, the new SGP acknowledges the role of past debt in assessing a country's budgetary objectives ex-ante, but fails to condition deficits on past debt: deviations from MTOs are corrected in a fixed proportion of GDP and faster adjustment is typically enforced on countries characterized by relatively low debt ratios (see our discussion in section 3 above). Fourth, the new Pact provides at best limited discipline for national fiscal policies that do not breach the $3 \%$ ceiling. In our view, this is a crucial weakness of the new Pact, as the slow pace of debt reduction in the early years of EMU was mainly due to insufficient deficits adjustment when growth was relatively fast. 
A controversy between the Italian Treasury Minister and the Commission provides an illuminating example of the unresolved issues with the new $\mathrm{SGP}^{19}$. After soaring to $4.4 \%$ of GDP in 2006, the Italian budget deficit fell to $2.4 \%$ in $2007,0.4 \%$ below the announced target. In the light of increasing revenues and in contrast with the government's plan to maintain a stable deficit, the Commission argued that the deficit cut should become more aggressive and continue with a further reduction of $0.5 \%$ in 2008 . The Commission's recommendation was certainly consistent with the SGP provisions. The Italian government replied that the unexpected deficit reduction was due to a structural reduction of tax evasion and that part of the extra revenues should return to citizens in the form of lower taxes. Needless to say, the Italian Government had the last word and the frictions with the Commission were barely noticed outside the economic and financial press. This episode confirms that enforcing further discipline when the deficit is within the $3 \%$ limit remains virtually impossible.

Given the above criticisms, our key result presented in condition (9) provides a rationale for advocating further amendments to the new SGP, concerning the procedure for admitting deviations from previously announced deficit targets and the subsequent process of debt correction. In fact, the optimal budget deficit can be decomposed into a cyclical component and negative feedback on accumulated debt deviation from the steady state. Obtaining uncontroversial information about shocks and making it costly to slow down debt adjustment are crucial prerequisites to discipline fiscal policies. Yet these issues have been hotly debated in the past and limiting governments' discretion in these areas has proven very difficult. Our proposal moves from the consideration that the EMU is a currency area where decisions over fiscal policies are decentralized and national governments remain jealous of their prerogatives. Critics of the SGP always maintained that member governments were unlikely to impose sanctions on their peers. Under the new SGP the situation has not changed. Insofar as governments are unwilling to delegate control of budget deficits to supra-national authorities, the power to discipline fiscal policies rests in the hands of

\footnotetext{
${ }^{19}$ See Tamborini (2007) for a detailed discussion.
} 
voters. The design of EMU institutions should therefore strengthen the transparency of the decision making process. In our view, this can be achieved by defining a clearer and more focused task for the Commission and assigning a more active role to national Parliaments whenever a disagreement arises between the Commission and the government.

Our proposal is articulated in three steps. First, and foremost, consistency between promises of future debt reversal at an appropriate speed (made in bad times) and subsequent policy actions (to be implemented in good times) should replace the size of the current deficit as the key to identify sound fiscal policies. Therefore, whenever governments choose to deviate from preannounced policies they should also spell out the subsequent corrections. Second, EMU institutions should provide a formal assessment of government plans. In this regard, the Commission should: $i$ ) express a view on revisions of macroeconomic forecasts and proposed countercyclical actions; ii) spell out the long-term implications of fiscal policy deviations from MTOs, irrespective of their size, when they entail a deficit increase; iii) recommend what in its view would be the necessary deficit adjustments in good times (when governments typically prefer inaction). Note that we leave the choice of immediate reactions to adverse shocks in the hands of national governments, but assign the Commission a crucial role in evaluating the appropriateness of the correction strategy. This is fully consistent with the enforcement mechanism outlined in section 4 (eq. 8 and 9). Third, EMU institutions should be endowed with the ability to generate political costs for non-complying fiscal policymakers. To obtain this, new provisions should require that, in case of disagreement with the Commission, the government would then be required to report to national Parliament, publicly motivating its decisions. In our view, this simple, transparency-enhancing amendment to the Pact would raise the political cost of disregarding the Commission's advice without strong justifications.

Would this be enough? Our proposal for fiscal policy mirrors the successful inflation targeting schemes in New Zealand and UK. In New Zealand the government chooses the inflation target. Then, every six months the Bank publishes a report outlining its future policy actions. This 
report is submitted to Parliament and can be discussed by a selected committee (Mishkin and Posen, 1997, p. 36). Despite early criticism of the scheme (McCallum, 1995; Waller, 1995), the Bank has been able to preserve price stability. In the UK, after the 1992 Sterling crisis, the government adopted a regime of inflation targeting, but the Bank of England was not granted independence until 1997. During this period, the Bank independently published an Inflation Report explaining the consequences of monetary policy actions. As observed in Mishkin (2000), the Inflation Report proved crucial in controlling inflation. In fact, the Bank of England made the most of the opportunity to communicate with the public "so that it could effectively act as the counterinflationary conscience for the government." (Mishkin, 2000, p. 18). In our view, The European Commission could act as the "sound fiscal conscience" for national governments, and public debates in national Parliaments could trigger media coverage sufficient to provide adequate information to voters.

\section{Conclusions}

Compared to the SGP, even in its 'new' post-2005 form, our proposal scores better with respect to the twin goals of long-term public finance sustainability and economic stabilization in the face of adverse shocks. In fact it leaves room for flexibility in bad times (when the SGP has proven unduly restrictive) and imposes discipline in good times (when the SGP cannot bite because it is asymmetric). Moreover, our proposal places enforcement powers in the hands of the collective will of national voters. Thus the credibility of the scheme ultimately rests on the reputational damage that governments would suffer from an open conflict with the European Commission. Effective communication of the Commission's view is the key to success in disciplining national fiscal policies. This also hints at an intriguing explanation for the failure of the old SGP: the Commission never managed to call for sufficient public opinion attention on the consequences of national fiscal policies. 
Critics might argue that our efforts to improve the SGP are in vain since the current economic crisis has de facto obliterated the Pact. In our view, our comparison with fiscal policies implemented in non-EMU countries once more confirms that the SGP binds when it should not. We are also convinced that in its present form it will bind when the recovery eventually takes place and implementation of an exit strategy that ensures control of public finances is necessary to preserve EMU macroeconomic stability in the longer run. Indeed, the current debt crisis in Greece and other EMU countries emphasises the need for a deficit-reduction rule which fully take into account debt sustainability. Given the well-documented difficulty in enforcing fiscal discipline in good times, this is the time for designing new rules such as the ones advocated in the paper. 


\section{Appendix}

We present solutions in a general form encompassing both discretion and the debt targeting rule. This requires that, in addition to conditions (1), (2), (4) we use:

$$
k_{1} g_{i, t}+k_{3}\left(D_{i, t}-\bar{D}\right)-\beta k_{1} E_{t}\left(g_{i, t+1}\right) \alpha(1+r)=0
$$

where $\bar{D}, \alpha$ are dichotomous variables that take values $[\widetilde{D}, 1]$ under fiscal discretion and $\left[\widetilde{D}^{T}, \alpha^{*}\right]$ under a debt targeting rule.

The solutions for debt and expenditures are obtained as in Tirelli (2001), which closely follows Jensen $(1994)^{20}$ :

$$
\begin{gathered}
\left.D_{s s}=\left\{\frac{k_{3}}{k_{1}}\left(1+k_{1}\right)-\frac{\widetilde{G}}{r}\left[(1+r)^{2} \beta \alpha-(1+r)\right]\right\} \hat{\Theta}-(1+r)\right]^{-1} \\
g_{s s}=-\frac{k_{3}}{k_{1}}[\hat{\Theta}-(1+r)] \\
D_{t}-D_{t-1}=\left(\frac{(1+r)}{\hat{\Theta}}-1\right)\left(D_{t-1}-D_{s s}\right)-\frac{\varepsilon_{t}}{\hat{\Theta}} \\
g_{t}=g_{s s}-\frac{\hat{\Theta}-1}{\hat{\Theta}\left(1+k_{1}\right)}(1+r)\left(D_{t-1}-D_{s s}\right)+\frac{\hat{\Theta}-1}{\hat{\Theta}} \frac{\varepsilon_{t}}{\left(1+k_{1}\right)}
\end{gathered}
$$

where $D_{s s}$ and $g_{s s}$ denote steady state levels and $\hat{\Theta}=\left[(1+r)^{2} \beta \alpha-1\right]+\frac{k_{3}}{k_{1}}\left(1+k_{1}\right)$.

Under discretion, tolerating debt deviations from $\widetilde{D}$ is costly for the fiscal policymaker. As a consequence, discretionary fiscal policies cause excessive debt accumulation in steady state. i.e.

$$
D_{s s}^{G}=\left\{\widetilde{D} \frac{k_{3}}{k_{1}}\left(1+k_{1}\right)-\frac{\widetilde{G}}{r}\left[(1+r)^{2} \beta-(1+r)\right]\right\}[\hat{\Theta}-(1+r)]^{-1}
$$

This, in turn, increases distortionary taxation and determines a negative expenditure gap (see equation 11). The model therefore replicates one of the "stylized facts" about fiscal policies in EMU, i.e. excessive accumulation of debt in the long run when fiscal policymakers retain full

\footnotetext{
${ }^{20}$ As the equilibrium is symmetrical we drop subfix $i$
} 
discretion. In contrast, a targeting rule, where $\widetilde{D}^{T}=-\widetilde{G} / r$, would completely eliminate steady state fiscal distortions.

Let us now turn to the analysis of dynamics. The model is stable for $\frac{(1+r)}{\hat{\Theta}}<1$. The sensitivity of expenditures to the current debt burden (equation 13) may be interpreted as follows. A change in debt service payments must be matched by a symmetric adjustment in the present value of current and expected primary surpluses, which is measured by $\left\{-\left(1+k_{1}\right)\left(\frac{\hat{\Theta}-1}{\hat{\Theta}}\right)^{-1} E\left(g_{t}\right)\right\}$. The term $\frac{\hat{\Theta}-1}{\hat{\Theta}}$ defines the proportion of the total adjustment implemented immediately ${ }^{21}$. Observe that $\hat{\Theta}$ is increasing in $\beta^{22}$. Thus, the more short-sighted are the governments relative to a social planner $\left(\beta<\beta^{*}\right)$, the stronger is the deficit sensitivity to shocks and the greater is the (inefficient) persistence of debt deviations from steady state. The policymaker's reluctance to tolerate debt deviations from the target works in the opposite direction: the larger is coefficient $k_{3}$, the less sensitive is the deficit to shock. By setting

$$
\alpha^{*}=\frac{\beta^{*}}{\beta}-\frac{k_{3}}{k_{1}} \frac{\left(1+k_{1}\right)}{(1+r)^{2} \beta}
$$

socially optimal dynamics are restored.

\footnotetext{
${ }^{21}$ Note that $(\hat{\Theta}-1) / \hat{\Theta}>0$ is a necessary condition for stability, and that the stability condition $\hat{\Theta}>(1+r)$ can be reinterpreted as a ceiling to the proportion of adjustment shifted onto the future.

${ }^{22}$ This is true for $(1+r)^{2} \beta>1$, which we assume to hold. In fact, Tirelli (2001) shows that failing this condition the intertemporal budget constraint is satisfied only under a balanced budget rule.
} 


\section{Acknowledgements}

The authors wish to thank for very useful comments Enzo Dia and Jacques Melitz. 


\section{References}

Alesina, A. and Perotti, R. (1995), Fiscal Expansion and Adjustments in OECD Countries, Economic Policy, vol. 21, 207-47.

Alesina, A. and Tabellini, G. (1987), Rules and Discretion with Noncoordinated Monetary and Fiscal Policies, Economic Inquiry, 619-30.

Alesina, A. and Tabellini, G. (1989), A Positive Theory of Fiscal Deficits and Government Debt, Review of Economic Studies, vol. 57, 403-414.

Almunia, J. (2004), Statement by Commissioner Joaquín Almunia on the revision of Greek deficit and debt data, http://europa.eu/rapid/pressReleasesAction.do?reference=IP/04/1135

Annett, A. (2006), Enforcement and the Stability and Growth Pact: How Fiscal Policy Did and Did Not Change Under Europe's Fiscal Framework, IMF Working Papers, WP/06/116.

Artis, M. J. and Onorante, L. (2006), The Economic Importance of Fiscal Rules, CEPR Discussion Paper, 5684.

Bean, C. (1998), The Stability Pact: More than a Minor Nuisance? Discussion, Economic Policy, vol. 0, 64-67.

Beetsma, R. and Bovenberg, A. L. (1997), Central Bank Independence and Public Debt Policy, Journal of Economic Dynamics and Control, vol. 21, 873-894.

Beetsma, R. and Bovenberg, L. (1999), Does monetary unification lead to excessive debt accumulation?, Journal of Public Economics, vol. 74, p. 299-325.

Beetsma, R. and Debrun, X. (2007) "The new stability and growth pact: A first assessment" European Econimic Review, 2007, vol. 51, issue 2, pages 453-477

Buiter, W.H. (2005), “The 'Sense and Nonsense of Maastrcht' Revisited: What Have We Learnt about Stabilization in EMU?", CEPR Discussion Paper, 5405.

Buti, M., Eijffinger S. and Franco, D. (2005), The Stability Pact Pains: A Forward-Looking Assessment of the Reform Debate, Center Working Paper No. 2005-101

Buti, M., Werner R. and In't Veld, J. (2001) "Stabilizing Output and Inflation: Policy Conflicts and Co-operation under a Stability Pact” Journal of Common Market Studies 39 (5) 801-828

Calmfors, L. (2005), "What Remains of the Stability Pact and What Next?”, Sieps, Report n 8.

Calmfors, L., Corsetti, G., 2003. How to reform Europe's .scal framework. World Economics 4 (1), $109-116$.

Canzoneri, M. and Diba, B. T. (2001), The SGP: delicate balance or albatross?, in Brunila, A., Buti, M. and Franco, D. (eds.), The Stability and Growth Pact: The Architecture of Fiscal Policy in $E M U$, The Palgrave.

CESifo (2002), Special Report On The European Economy, downloadable from http://www.cesifo.de/ 
Coeré, B. and J. Pisani-Ferry (2005), "Fiscal Policy in EMU: Towards a Sustainability and Growth Pact?", Oxford Review of Economic Policy, 2005 21(4):598-617

Cukierman, A., and Meltzer, A. (1989), A Political Theory of Government Debt and Deficits in a Neo-Ricardian Framework, American Economic Review, vol. 79, 713-748.

Dixit, A. and Lambertini, L. (2000), Fiscal Discretion Destroys Monetary Commitment, WP http://econweb.sscnet.ucla.edu/lambertini/papers/eea2000.pdf.

European Commission (2005), Public Finances in EMU-2005, European Economy, n.3.

European Commission (2008), Public Finances in EMU-2008.

European Commission (2009), Public Finances in EMU-2009.

Fatas, A., von Hagen, J., Hallett, A.H., Strauch, R., Sibert, A., 2004. Stability and Growth in Europe: Towards a Better Pact. Monitoring European Integration, vol. 13, Center for Economic Policy Research, London.

IMF (2009) Group of Twenty Meeting of the Ministers and Central Bank Governors March 13-14, 2009 London, U.K. Global Economic Policies and Prospects http://www.imf.org/external/np/g20/pdf/031909a.pdf

Jensen, H. (1994), Loss of Monetary Discretion in a Simple Dynamic Policy Game, Journal of Economic Dynamics and Control, vol. 18, 763-779.

McCallum, B., (1995), Two Fallacies Concerning Central Bank Independence, American Economic Review, Papers and Proceedings,85, 207-11.

Mishkin, F. and Posen, A. (1997), Inflation Targeting: Lessons from four countries, NBER Working Paper n. 6126

Mishkin, F. (2000), From monetary targeting to inflation targeting: Lessons from the industrialized countries, mimeo

Persson, T. and Svensson, L. (1989), Why a Stubborn Conservative Would Run a Deficit: Policy with Time Inconsistent Preferences, Quartely Journal of Economics, vol. 104, 325-345.

Rehn, O. (2010). Reinforcing economic governance in Europe European Policy Centre, Brussels http://pr.euractiv.com/print/feed-result/olli-rehn-european-commissioner-economic-and-monetarypolicy-reinforcing-economic-govern

Rotemberg, J. and Woodford, M. (1997), An Optimization-based Econometric Framework for the Evaluation of Monetary Policy, NBER Macroeconomic Annual, vol. 12, 297-346.

Rotemberg, J. and Woodford, M. (1999), Interest-Rate Rules in an Estimated Sticky-Price Model, in J. Taylor, (ed.) Monetary Policy Rules, University of Chicago Press, Chicago.

Svensson, L., (1997), Optimal Inflation Targets, "Conservative" Central Banks and Linear Inflation Contracts, American Economic Review. 
Strauch, R., Hallberg, M. and von Hagen, J. (2004), Budgetary Forecasts in Europe - The Track Record of Stability and Convergence Programmes, ECB Working Paper n. 307.

Tabellini, G. (1986), Money, Debt and Deficits in a Dynamic Game, Journal of Economic Dynamics \& Control. vol. 10, 427-42.

Tamborini, R. (2007), The New Stability and Growth Pact: A View from Italy, Europe EconoMonitor http://www.rgemonitor.com/euro-monitor, downloadable from http://wwwceel.economia.unitn.it/corsomittone/tamborini/ps1.pdf

Tirelli, P. (2001), Revisiting Public Debt and Inflation: Fiscal Implications of an Independent Central Banker, Università di Milano Bicocca WP 31

Turrini A. (2008), Fiscal Policy and the cycle in the Euro Area: The role of government revenue and expenditures, European Economy.

von Hagen, J. (2005), Fiscal Rules and Fiscal Performance in the EU and Japan, CEPR Working Paper n. 5330.

Waller, C., (1995) , Performance Contracts for Central Bankers, Federal Reserve Bank of St. Louis, 77, 3-14.

Wyplosz, C., 2005. Fiscal policy: institutions versus rules. National Institute Economic Review $191,64-78$. 